\title{
ANALISIS FAKTOR RISIKO IBU DAN ANAK BALITA TERHADAP STUNTING DI WILAYAH KERJA PUSKESMAS SANGURARA
}

\author{
Rahmawati Azis ${ }^{1}$, Muhammad Rifai ${ }^{2}$ dan Ni Ketut Setiahati ${ }^{3}$ \\ Pascasarjana Sekolah Tinggi Ilmu Kesehatan Tamalatea Makassar \\ rahmaazis@stiktamalateamks.ac.id ${ }^{1}$,m.rifai@ stiktamalateamks.ac.id ${ }^{2}$, \\ 019140068@stiktamalateamks.ac.id ${ }^{3}$
}

\begin{abstract}
Stunting is a form of failure to grow and develop children, due to chronic malnutrition, which will have the potential for the child's body to become stunted. Based on data from the Palu City Health Office in 2020, it shows that the Sangurara Health Center has the highest stunting cases, as many as $373(35.26 \%)$. The purpose of the study was to determine the risk factors for mothers and children under five to the incidence of stunting. The research method is analytic observational with case control design. The research population was the total number of mothers and children under five who came to visit the Sangurara Health Center as many as 373 people. The samples studied were 79 people. The sample was determined by purposive sampling (case) and simple random sampling (control). The research data were analyzed by chi square, Odd Ratio test, and logistical regression. The results showed that there were risk factors for maternal age during pregnancy, mother's educational, family income, maternal nutritional status during pregnancy, and history of diarrhea on the incidence of stunting in children under five. Multivariate analysis showed that the risk factor for age at pregnancy $(O R=7,521 ; 95 \%$ CI 1,690-33,467), education (OR=5,488;95\%CI 1,281-23,503), maternal nutritional status during pregnancy (OR=0,041; 95\%CI 0,006-0,294), and history of diarrhea $(O R=0,155 ; 95 \%$ CI 0,037-0,651). The conclusion is that age during pregnancy is the most risk factor for stunting. It is recommended to minimize the risk of stunting by giving serious attention to preventing early marriage so that mothers during pregnancy are at a healthy reproductive age. Special attention should also be paid to mothers with low education, improving maternal nutrition during pregnancy, and children who often suffer from diarrhea.
\end{abstract}

Keywords $\quad$ : children under five, pregnant, risk factors, stunting

\begin{abstract}
ABSTRAK
Stunting adalah bentuk kegagalan bertumbuh dan berkembangnya anak, karena adanya malnutrisi kronis, yang akan berpotensi tubuh anak menjadi kerdil. Berdasarkan data Dinkes Kota Palu Tahun 2020, Puskesmas Sangurara memiliki kasus stunting tertinggi, yaitu sebanyak 373 (35,26\%). Tujuan penelitian untuk mengetahui faktor ibu dan anak balita risikonya terhadap terjadinya stunting. Metode penelitian yaitu observasional analitik desain kasus kontrol. Populasi yakni ibu dan anak balita yang mendatangi Puskesmas Sangurara sebanyak 373 orang. Sampel 79 orang. Kasus ditetapkan dengan purposive sampling dan kontrol menggunakan sampling random sederhana. Data dianalisis uji chi square, Odd Ratio, dan regresi logistik. Analisis bivariat menyatakan ada faktor risiko ibu (usia hamil, pendidikan, pendapatan, status gizi saat hamil), dan riwayat diare balita terhadap kejadian stunting. Analisis multivariat menunjukkan usia ibu ketika hamil $(\mathrm{OR}=7,521 ; 95 \% \mathrm{CI} 1,690-33,467)$, pendidikan $(\mathrm{OR}=5,488 ; 95 \% \mathrm{CI} 1,281-23,503)$, gizi ibu saat hamil $(\mathrm{OR}=0,041 ; 95 \%$ CI $0,006-0,294)$, dan riwayat diare (OR=0,155;95\% CI 0,037-0,651). Kesimpulannya adalah usia ketika hamil merupakan faktor yang paling berisiko mengalami anak balitanya stunting. Disarankan untuk memberi perhatian secara serius mencegah pernikahan usia dini agar ibu saat hamil berada pada usia reproduksi sehat. Harus pula memberikan perhatian khusus kepada ibu dengan pendidikan rendah, status gizi ibu selama kehamilan, dan diare pada balita.
\end{abstract}

Kata Kunci $\quad$ : Balita, Kehamilan, Faktor Risiko, Hamil, Stunting 


\section{PENDAHULUAN}

Fokus program menjadi prioritas pembangunan bidang kesehatan Tahun 2020-2024 yaitu ibu dan bayi, bagaimana menurukan angka kematiannya, prevalensi menurun untuk kasus stunting balita, perbaikan pengelolaan JKN, peningkatan kemandirian dan penggunaan produk farmasi dan alkes dalam negeri. Upaya pembangunan nasional yang menjadi salah satu prioritas termuat dalam sasaran RPJMN Tahun 2020-2024 yaitu upaya meningkatkan status gizi dan menurunkan prevalensi balita pendek (Litbangkes, 2020).

Sustainable Development Goals (SDG's) ketercapaiannya pada Tahun 2030 di antaranya yaitu seluruh macam bentuk kekurangan nutrisi akan diprioritaskan, dan akan menggapai target internasional 2025 dalam menurunkan angka prevalensi anak anak yang kurus (wasting) dan anak yang pendek (stunting) serta kebutuhan gizi pada anak balita, remaja wanita, ibu hamil dan menyusu, serta usia renta (lanjut) dapat terpenuhi (Kementerian PPN, 2020).

Stunting merupakan keadaan di mana anak di bawah 5 tahun tidak dapat berkembang karena malnutrisi dengan durasi lama (kronis), hingga berdampak anak berpostur pendek jika merujuk tinggi badan anak yang seusianya. Malnutrisi gizi ini terjadi pada janin saat dikandung hingga dua tahun kehidupan setelah bayi lahir. Namun, stunting baru akan muncul ketika anak berusia di atas 2 tahun. Anak dengan keterlambatan tumbuh kembang merujuk pada Tinggi Badan (TB)/ Panjang Badan (PB) anak berdasarkan umur (U) dengan nilai MGRS (Multicentre Growth Reference Study) oleh World Health Organization/WHO (TNP2K, 2017).

Anak balita memiliki nilai $\mathrm{z}<-2 \mathrm{SD}$ (keterlambatan perkembangan) dan <-3SD (keterlambatan perkembangan yang parah) Usia 24-59 bulan merupakan masa kritis untuk memperoleh kualitas sumber daya manusia, utamanya pada masa emas bagi otak dalam pertumbuhan dan perkembangannya yang optimal pada tahun pertama, perlu menjadi perhatian serius.

Tanda-tanda stunting merupakan efek dari pertumbuhan yang lambat dan kekurangan asupan makronutrien dan mikronutrien kronis atau akibat infeksi kronis.Tumbuh kembang anak dipengaruhi oleh 3 faktor yakni pertama: individu, antara lain asupan gizi, berat badan saat lahir, infeksi penyakit yang diderita, dan faktor lingkungan. Stunting disebabkan karena kurangnya nutrisi dari berbagai makanan. Stunting juga bisa disebabkan karena mengonsumsi makanan yang tidak sehat (seperti minuman berkarbonasi yang mengganggu metabolisme tulang). Faktor sosial ekonomi lain yang memengaruhi kejadian stunting antara lain pengeluaran makanan, pendidikan, pendapatan, dan pekerjaan orang tua. Dalam jangka pendek, kemungkinan dampak terburuk dari masalah gizi anak adalah perkembangan otak, gangguan perkembangan intelektual dan fisik serta gangguan proses metabolisme di dalam tubuh. Dalam jangka waktu yang panjang, kemungkinan konsekuensi yang tidak diinginkan yaitu penurunan kapasitas kognitif dan kemampuan akademik, daya tahan tubuh yang rendah, rentan penyakit, risiko tinggi diabetes, obesitas, kanker, penyakit pembuluh darah dan jantung, stroke dan ketidakmampuan atau keterbatasan lanjut usia, serta kerja yang tidak berkualitas dan berdaya saing yang menyebabkan menurunnya daya produksi ekonomi (Kemenkes, 2021).

Stunting pada anak menjadi masalah urgen karena dapat meningkatkan angka morbiditas dan mortalitas menjadi tinggi di masa depan, penyakit degeneratif, obesitas, perkembangan kemampuan pemahaman/ kognitif yang buruk, dan penurunan pendapatan serta produktivitas kerja. Menurut Organisasi Kesehatan Dunia, stunting didefinisikan sebagai 
ketinggian di bawah kurva pertumbuhan rata-rata anak-anak sesuai rujukan usia dan jenis kelamin yang sama (Trihono et al., 2015).

Stunting berdampak jangka waktu panjang yaitu terganggunya kognitif, intelektual, fisik dan mental yang perkembangan menjadi lambat, masih menjadi permasalahan gizi di negara Indonesia. Anak yang menderita stunting sampai berada diusia 5 tahun maka sulit untuk diperbaiki dan akan meningkatkan berbagai masalah nantinya sehingga dapat berlanjut sampai dewasa. Tahun 2017 sebanyak 22,2\% (150,8 juta) mengalami stunting di seluruh belahan dunia, lebih dari setengahnya dari Asia. Indonesia negara ketiga tercatat prevalensi stunting paling tinggi di Asia Tenggara. Organisasi WHO mencantumkan, yaitu $36,4 \%$ (Kemenkes RI, 2018). Laporan UNSD (2014), Indonesia memiliki prevalensi balita stunting (pendek) tertinggi jika dipadankan dengan negara-negara tetangga di Asia Tenggara, yakni 4 persen Singapura, 16 persen Thailand, 17 persen Malaysia, 23 persen Vietnam, dan 35 persen Myanmar (Kemenkes RI, 2016).

Tahun 2013 balita sangat pendek dan pendek sekitar 37,2\%. Angka tersebut meningkat dari angka sebelumnya tahun 2010 tercatat $35,6 \%$. Namun, pada tahun 2018, menurut data Riskesdas, prevalensi stunting turun menjadi $29,6 \%$, di mana sebelumnya tahun 2013, stunting mencapai 37,2\% (Balitbangkes, 2019). Di tahun 2019, keseluruhan gizi balita mengalami peningkatan dibandingkan tahun sebelumnya (Sudikno et al., 2019). Meskipun di Indonesia telah terjadi penurunan prevalensi stunting dari tahun ke tahun, namun penurunan prevalensi stunting masih berada di atas standar ketentuan dari Badan Kesehatan Organisasi Dunia. WHO memutuskan bahwa masalah kejadian stunting di setiap wilayah sebesar 20\%. Kondisi Indonesia pada tahun 2019, prevalensi stunting masih mencapai angka sebesar 27,67\% untuk kasus stunting balita (Kemenkes, 2020).

Beberapa variabel memengaruhi status gizi seseorang, terbagi menjadi dua faktor penyebab. Penyebab yang langsung mencakup intake makanan dan penyakit infeksi/menular, yang saling memengaruhi. Penyebab secara tidak langsung mencakup lingkungan tempat tinggal sanitasinya, penyediaan air bersih, tersedianya pangan, pengasuhan anak, layanan kesehatan berkuaitas, Pendidikan formal, penghasilan keluarga dan informasi yang diperoleh (Kementerian PPN/Bappenas, 2019).

Berbagai penelitian sebelumnya telah dilakukan untuk menganalisis beberapa faktor/ variabel yang dianggap menyebabkan terjadinya stunting pada anak balita. Menurut Imelda, et al. (2018) tentang faktor risiko terjadinya stunting pada anak 2-5 tahun di Puskesmas Biromaru menemukan bahwa pola asuh, imunisasi dasar, pemberian makan, BBLR dan garam beryodium menjadi faktor risiko terjadinya stunting. Pada penelitian Setiawan \& Machmud (2018) menunjukkan adanya hubungan bermakna antara berat badan lahir, intake gizi (energi), riwayat penyakit infeksi/menular, pendapatan keluarga, dan pendidikan dengan kejadian stunting. Pendidikan ibu yang memiliki hubungan paling berpengaruh terhadap kejadian stunting. Penelitian Sutriyawan et al. (2020) menemukan faktor adanya hubungan dengan stunting yakni ASI eksklusif, pengetahuan ibu, dan sanitasi lingkungan.

Penelitian Indriani, et al. (2018), menunjukkan bahwa adanya variabel yang memiliki hubungan bermakna dengan kejadian stunting mencakup panjang badan anak saat lahir, kunjungan posyandu, tinggi badan ibu, dan jumlah anggota keluarga. Selanjutnya menurut Venuz et al., (2019), penelitiannya menemukan risiko stunting yakni jenis kelamin, asupan energi, status ekonomi keluarga, berat badan lahir balita, riwayat 
penyakit infeksi, status imunisasi, pendidikan, pekerjaan orang tua, dan pemberian ASI eksklusif. Sedangkan dalam penelitian Hasan \& Kadarusman (2019) menemukan bahwa ketersediaan sumber air bersih dan jamban yang memenuhi syarat kesehatan menjadi faktor risiko stunting setelah dikontrol oleh variabel pemantauan pertumbuhan, Riwayat makanan pendamping ASI, dan penyakit infeksi.

Mengacu pada penelitian di atas, faktor ibu yaitu riwayat kehamilan, antara lain perawakan ibu pendek, jarak persalinan terlalu rapat, banyak paritas, usia ibu ketika hamil, dan usia kehamilan ibu menjadi beberapa faktor yang menjadi penyebab keterlambatan perkembangan anak. Terlalu muda (di bawah 20 tahun) untuk melahirkan bayi dengan berat badan lahir rendah, serta nutrisi yang tidak mencukupi selama ibu hamil. Faktor lain, bersumber dari faktor anak yaitu antara lain kegagalan pemberian ASI eksklusif, ketidakberhasilan penerapan inisiasi menyusu dini (IMD), dan terlalu awal anak disapih. Selain hal tersebut, kondisi sanitasi lingkungan, dan sosial ekonomi juga memengaruhi stunting (Kemenkes RI, 2018).

Di Provinsi Sulawesi Tengah sendiri, prevalensi stunting pada balita berdasarkan data riskesdas tahun 2018 sebanyak $32,2 \%$. Menurut data Profil Dinkes Provinsi Sulawesi Tengah tahun 2019 stunting balita sebesar 21,4\% sedangkan untuk Kota Palu sebanyak 17\% (Profil Provinsi Sulawesi Tengah, 2020). Meskipun secara makro prevalensi stunting balita di Kota Palu tergolong rendah, namun secara mikro masih ditemukan adanya kejadian stunting (balita pendek/TB/U) yang cukup tinggi pada beberapa puskesmas yang ada di Palu.

Data Dinas Kesehatan Kota Palu, masih ditemukan adanya kejadian stunting (balita pendek/TB/U) pada anak balita di atas standar $20 \%$ dari WHO di wilayah kerja beberapa Puskesmas di Kota Palu, yaitu di Puskesmas Pantoloan 224

(31,07\%), Puskesmas Mamboro 94

(24,35\%), Puskesmas Sangurara 373

(35,26\%), dan Puskesmas Nosarara 271

(20,24\%). Kemudian keempat Puskesmas

di Kota Palu yang memiliki kejadian stunting (balita pendek/TB/U) di atas dari standarisasi yang dipersyaratkan WHO, nampak bahwa angka stunting tertinggi terjadi di wilayah Puskesmas Sangurara, berada di Kecamatan Tatanga Kota Palu. Sesuai dengan data di atas, maka penulis menetapkan Puskesmas Sangurara sebagai lokus penelitian, memiliki wilayah kerja mencakup 5 kelurahan yakni Duyu, Boyaoge, Nunu, Balaroa, dan Donggala Kodi dengan luas wilayah kerja $+13,69$ $\mathrm{km}^{2}$. Dari kelima kelurahan, terlihat kejadian stunting pada anak balita paling tinggi terjadi di Kelurahan Donggala Kodi sebanyak $98(39,8 \%)$ disusul Balaroa sebanyak 81 (36,5\%), Bayaoge dan Nunu sebanyak 39 (36,4\%), dan terakhir Kelurahan Duyu sebanyak 108 (30,5\%) (Sumber: Data Laporan Program Puskesmas Sangurara Tahun 2020). Kejadian stunting di wilayah kerja Puskesmas Sangurara, diduga disebabkan pengaruh beberapa faktor risiko seperti riwayat bayi memperoleh Makanan Pendamping Air Susu Ibu, usia ketika hamil, usia kandungan saat melahirkan, pendidikan, pendapatan keluarga, riwayat BBLR, riwayat diare, riwayat ISPA pada anak balita, sanitasi lingkungan, dan status gizi ibu saat hamil.

Kondisi di atas mengakibatkan adanya permasalahan atas upaya Puskesmas Sangurara mengatasi kejadian stunting di wilayah kerjanya. Realitas ini terjadi karena layanan aspek kesehatan belum maksimal diberikan oleh petugas kesehatan. Selain itu, masalah kondisi sosial ekonomi dan sanitasi di lingkungan masyarakat juga menjadi penyebab adanya kesenjangan (gap) dalam upaya Puskesmas Sangurara mengatasi kejadian stunting di wilayah kerjanya. 
Berdasarkan permasalahan yang ada dan didukung dengan fenomena yang telah disampaikan sebelumnya, peneliti bermaksud melakukan penelitian tentang analisis faktor risiko ibu dan anak balita terhadap Stunting pada anak balita di Wilayah Kerja Puskesmas Sangurara, Tatanga, Palu.

\section{METODE}

Jenis penelitian yakni kuantitatif analitik observasional, desain kasus kontrol. Peneliti mengamati hubungan/ faktor risiko paparan dan penyakit dengan cara mengindetifikasi lebih awal, kelompok kasus (stunting) dan kelompok orang yang sehat (normal), kemudian membandingkan proporsi paparan kelompok kasus dan kontrol.

Populasi yang diteliti yakni keseluruhan anak balita yang datang berkunjung di Wilayah Kerja Puskesmas Sangurara Kecamatan Tatanga sebanyak 373 anak balita (Puskesmas Sangurara, 2021). Besar sampel dari penelitian ini sebesar 79 anak balita di mana sampel kasus ditetapkan dengan purposive sampling dan sampel kontrol dengan teknik probability sampling metode sampling random sederhana.

Teknik analisis data digunakan terdiri dari analisis univariat (tabel frekuensi dan persentase), analisis bivariat (uji Odd Ratio dan Chi Square), sedangkan analisis multivariat (regresi logistik).

\section{HASIL}

\section{Univariat}

Jumlah sampel yang memiliki Tinggi Badan menurut Umur termasuk kategori kasus stunting sebanyak 40 orang $(50,6 \%)$ dan sampel kontrol 39 orang anak balita $(49,4 \%)$. Adapun analisis univariat karakteristik ibu dan anak balita ditampilkan dalam distribusi frekuensi di Tabel 1.
Tabel 1 dapat dilihat dari 79 responden, sebanyak 38 orang $(48,1 \%)$ pemberian MP-ASI saat anak balita berusia di bawah 6 bulan, 30 orang $(38 \%)$ ibu saat hamil berusia berisiko $(<20$ dan $>35$ tahun), 32 (40,5\%) usia kandungan ibu saat melahirkan kurang bulan, <37 minggu. Status pendidikan ibu, masih ada 36 responden $(45.6 \%)$ hanya tamatan SMP, sebanyak 36 responden $(45,6 \%)$ memiliki pendapatan keluarga di bawah Upah Minimum Kota Palu.

\section{Tabel 1. Distribusi Responden berdasarkan} Faktor Ibu dan Anak Balita

\begin{tabular}{|c|c|c|}
\hline Faktor Ibu dan Anak Balita & $\mathbf{f}$ & $\%$ \\
\hline \multicolumn{3}{|l|}{ Riwayat Pemberian MP-ASI } \\
\hline$<6$ Bulan & 38 & 48,1 \\
\hline$\geq 6$ Bulan & 41 & 51,9 \\
\hline \multicolumn{3}{|l|}{ Usia Ibu Saat Hamil } \\
\hline$<20 \&>35$ Tahun & 30 & 38,0 \\
\hline 20-35 Tahun & 49 & 62,0 \\
\hline \multicolumn{3}{|c|}{ Usia kandungan saat melahirkan } \\
\hline Kurang & 32 & 40,5 \\
\hline Cukup & 47 & 59,5 \\
\hline \multicolumn{3}{|l|}{ Status Pendidikan } \\
\hline Rendah ( $\leq$ Tamat SMP) & 36 & 45,6 \\
\hline Tinggi ( $\geq$ Tamat SMA) & 43 & 54,4 \\
\hline \multicolumn{3}{|l|}{ Pendapatan Keluarga } \\
\hline Rendah $(<$ UMK) & 36 & 45,6 \\
\hline Tinggi $(\geq \mathrm{UMK})$ & 43 & 54,4 \\
\hline \multicolumn{3}{|l|}{ Riwayat BBLR } \\
\hline $\mathrm{Ya}(\mathrm{BBL}<2500 \mathrm{gr})$ & 43 & 54,4 \\
\hline Tidak (BBL $\geq 2500$ gr) & 36 & 45,6 \\
\hline \multicolumn{3}{|c|}{ Riwayat Diare Balita (6 bulan terakhir) } \\
\hline Menderita & 34 & 43,0 \\
\hline Tidak Menderita & 45 & 57,0 \\
\hline \multicolumn{3}{|c|}{ Riwayat ISPA Balita (6 bulan terakhir) } \\
\hline Menderita & 19 & 24,1 \\
\hline Tidak Menderita & 60 & 75,9 \\
\hline \multicolumn{3}{|l|}{ Sanitasi Lingkungan } \\
\hline Baik & 47 & 59.5 \\
\hline Buruk & 32 & 40,5 \\
\hline \multicolumn{3}{|l|}{ Status Gizi Saat Hamil } \\
\hline Kurang & 18 & 22,8 \\
\hline Baik & 61 & 77,2 \\
\hline Jumlah & 79 & 100,0 \\
\hline
\end{tabular}

Lebih dari separuh $(54,4 \%)$ memiliki balita dengan riwayat BBLR. Dalam enam bulan terakhir saat wawancara dilakukan, 
sebanyak $43 \%$ dan $24,1 \%$ pernah menderita diare dan ISPA. Lingkungan tempat tinggal responden yang memiliki sanitasi buruk masih cukup tinggi yaitu sebanyak $32(40,5 \%)$. Status gizi saat kehamilannya yang kurang (LILA <23,5 $\mathrm{cm})$ yaitu $22,8 \%$.

\section{Bivariat}

Hasil analisis bivariat ditampilkan seperti pada Tabel 2 .

Tabel 2. Analisis Faktor Risiko Ibu dan Balita terhadap Stunting




Tabel 3. Hasil Perhitungan Regresi Logistik

\begin{tabular}{lrc}
\hline \multicolumn{1}{l}{ Faktor Risiko } & \multicolumn{1}{c}{ Sig. } & OR $(95 \%$ CI $)$ \\
\hline Usia ketika & 0,008 & 7,521 \\
hamil & $(<0,01)$ & $(1,690-33,467)$ \\
Pendidikan & 0,022 & 5,488 \\
& $(<0,05)$ & $(1,281-23,503)$ \\
Riwayat diare & 0,011 & 0,155 \\
& $(<0,05)$ & $(0,037-0,651)$ \\
Status gizi saat & 0,001 & 0,041 \\
hamil & $(<0,01)$ & $(0,006-0,294)$ \\
\hline
\end{tabular}

Sesuai dengan analisis multivariat, maka diperoleh hasil bahwa usia ibu saat hamil pendidikan ibu, riwayat diare balita, dan gizi saat hamil yang memengaruhi kejadian stunting. Hasil perhitungan terlihat di Tabel 3.

Berdasarkan Tabel 3, diketahui bahwa dari faktor risiko yang diamati dalam analisis multivariat, terdapat 3 faktor ibu dan 1 faktor dari balita yang memengaruhi kejadian stunting. Faktor tersebut adalah yaitu usia ibu saat hamil (OR=7,521;95\%CI 1,690-33,467), pendidikan $\quad(\mathrm{OR}=5,488 ; 95 \% \mathrm{CI} \quad 1,281$ 23,503), gizi ibu saat hamil (OR=0,041;95\% CI 0,006-0,294), dan riwayat diare $(\mathrm{OR}=0,155 ; 95 \%$ CI 0,037 $0,651)$.

\section{PEMBAHASAN}

\section{Faktor risiko usia ibu}

Analisis bivariat dengan chi square (nilai $\mathrm{p}=0,002<0,05$ ) dan OR faktor usia ibu saat hamil sebesar 0,193 (CI95\% 0,071-0,525) yang dapat diartikan bahwa faktor usia ibu saat hamil berisiko 0,193 kali terhadap stunting di wilayah Puskesmas Sangurara. Kemudian pada hasil analisis multivariat dengan metode regresi logistik, menunjukkan faktor risiko usia ibu saat hamil memiliki nilai OR sebesar 7,521 (95\%CI 1,690-33,467). Hal ini menunjukkan usia ibu saat hamil merupakan faktor risiko kejadian stunting pada anak balita di wilayah kerja Puskesmas Sangurara.
Hasil penelitian ini juga sejalan dengan penelitian Larasati et al. (2018) yang menunjukkan adanya hubungan yang signifikan antara kehamilan remaja dengan kejadian stunting pada balita ( $\mathrm{p} 0,016)$ dengan nilai $\mathrm{OR}$ adalah 3,86 . Semakin muda usia ibu mengalami kehamilan, maka akan bepeluang semakin besar risiko anak mengalami stunting.

Usia ibu yang memenuhi syarat ideal hamil dan melahirkan merupakan intervensi gizi sensitif yang dapat berkontribusi $70 \%$ dalam menurunkan stunting, khususnya dalam penyediaan fasilitas layanan keluarga berencana (KB). Usia tepat bagi perempuan untuk hamil dan melahirkan yaitu usia 20-35 tahun dikarenakan pada kelompok usia tersebut wanita menghadapi risiko berbahaya paling rendah. Wanita yang hamil pada usia muda, di bawah 20 tahun, jika ditinjau dari sudut biologis, belum optimalnya perkembangan sistem reproduksi sehingga berpeluang akan mendapat gangguan kesehatan. Begitupula wanita di atas 35 tahun mengalami hamil pada usia tersebut, maka fungsi alat reproduksinya secara alamiah mengalami degeneratif dan peluang terjadinya penyakit atau masalah kesehatan seperti hipertensi, ginjal, diabetes mellitus, jantung, mellitus, dan sebagainya.

Pernikahan usia dini pada anak berdampak pada persalinan di usia dini yang menyebabkan tingginya angka kematian dan kelahiran ibu pada usia di bawah 18 tahun, juga mempunyai risiko kematian bayi, lahir prematur dan stunting (Windiarto et al., 2018).

\section{Faktor risiko status pendidikan ibu}

Berdasarkan pada hasil analisis statistik bivariat dengan metode ChiSquare menunjukkan ada hubungan antara faktor risiko status pendidikan ibu dengan kejadian stunting pada anak balita di wilayah kerja Puskesmas Sangurara. Hal ini dibuktikan dengan nilai $p$ sebesar 0,033 $<0,05$, untuk faktor risiko status 
pendidikan ibu. Nilai OR faktor risiko status pendidikan ibu sebesar 0,335 (95\%CI 0,134-0,840) yang dapat diartikan bahwa faktor status pendidikan ibu berisiko 0,335 kali terhadap stunting.

Kemudian pada hasil analisis multivariat dengan metode regresi logistik, menunjukkan faktor risiko status pendidikan ibu memiliki nilai OR sebesar 5,488 pada tingkat kepercayaan 95\% CI $(1,281-23,503)$ dengan nilai $p$ sebesar $0,022<\alpha 0,05$. Ini menunjukkan faktor risiko pendidikan ibu memengaruhi kejadian stunting. Nilai OR sebesar 5,488 memberikan arti sebesar 5,5 kali risiko status pendidikan ibu terhadap kejadian stunting.

Sejalan dengan penelitian studi literatur review Apriluana et al. (2018) di Negara Berkembang dan wilayah Asia Tenggara, menunjukkan bahwa pendidikan rendah memiliki pengaruh bermakna, memiliki risiko stunting 1,67 kali pada anak usia bawah 5 tahun. Kebanyakan negara berkembang, khususnya Indonesia memiliki masyarakat dengan mayoritas pendapatan terbatas, di mana faktor budaya masih memengaruhi orang tua untuk lebih memilih anak jenis kelamin laki-laki dibandingkan anak perempuan berkesemapatan mengecap pendidikan tinggi. Pendidikan orang tua yang tinggi terutama ibu, telah menunjukkan pertumbuhan balita yang lebih baik, daripada ibu berpendidikan rendah.

Berdasarkan hasil penelitian (Tatu et al., 2021), peneliti menyatakan bahwa semakin tinggi pendidikan maka akan makin meningkat kemampuan menyerap informasi. Pendidikan orang tua, khususnya ibu akan memengaruhi proses penerimaan informasi luar, terutama tentang cara pengasuhan anak yang baik. Adanya ketidakmampuan dalam menyerap informasi dengan baik, khususnya mengenai gizi, maka kebutuhan gizi anak balita tidak akan terpenuhi. Hal tersebut akan berdampak tidak sesuai standar gizi pengolahan makanan balita, sehingga balita kemungkinan besar akan mengalami stunting.

Penelitian Wahyuni et al. (2020), analisis secara bivariat ditemukan bahwa pendidikan mempunyai hubungan signifikan dengan kejadian stunting ( $p<$ $0,05)$. Orang tua berpendidikan tinggi, lebih berorientasi pada perilaku pencegahan, mengetahui banyak hal terkait kesehatan, khususnya masalah gizi. Hal ini akan berkaitan dengan wawasan pengetahuan mengenai pola makan yang baik. Orang tua, terutama ibu yang berpendidikan rendah, akan kurang optimal memenuhi kebutuhan gizi anak, sehingga menyebabkan anak mengalami kekurangan gizi dalam masa pertumbuhannya.

Literasi bagi ibu akan pentingnya kesehatan sangat penting terutama perihal gizi keluarga terutama anak, karena dapat meningkatkan pemahaman ibu mengenai gizi dan kesehatan keluarga terutama gizi ibu dan anak.

\section{Faktor risiko riwayat diare balita}

Berdasarkan pada analisis bivariat dengan metode Chi-Square menyatakan ada faktor risiko riwayat diare terhadap kejadian stunting. Hal ini dibuktikan dengan nilai $p$ untuk faktor risiko riwayat diare balita sebesar 0,051 . Nilai OR faktor risiko riwayat diare balita 2,750 (95 CI 1,094-6,916), yang dapat diartikan bahwa faktor riwayat diare berisiko hampir $3 \mathrm{kali}$ terhadap kejadian stunting.

Analisis multivariat menunjukkan risiko riwayat diare memiliki nilai OR adalah sebesar 0,155 pada tingkat kepercayaan $95 \%$ CI $(0,037-0,651)$, dengan nilai $p$ sebesar $0,011<\alpha 0,05$. Hal ini menunjukkan bahwa faktor risiko riwayat diare balita memengaruhi kejadian stunting. Nilai OR sebesar 0,155 memberikan arti, setelah berintekasi bersama-sama dengan variabel lainnya, maka risiko riwayat diare balita terhadap 
kejadian stunting pada anak balita sebesar 0,2 kali.

Hasil penelitian yang relevan yakni penelitian Desyanti \& Nindya, (2017), yang mengemukakan bahwa diare berhubungan signifikan dengan kejadian stunting $(\mathrm{p}=0,025 ; \mathrm{OR}=3,619)$. Seorang anak yang mengalami diare, maka dapat menyebabkan gangguan penyerapan zat gizi dan jika durasi diare berlangsung kronis akan membuat anak semakin menderita karena kehilangan zat gizi, bila tidak segera ditangani melalui asupan yang sesuai, maka dapat mengalami kegagalan berkembang dan bertumbuh. Juga sejalan penelitian di Wilayah Kerja Puskesmas Kolono, menunjukkan bahwa stunting berisiko pada balita yang mengalami infeksi diare pada Balita Usia 24-36 Bulan. Stunting berisiko hampir 6 kali lebih besar pada mereka yang mengalami diare $(\mathrm{N}$. Wahyuni et al., 2019).

Daerah endemik Gaki di Timor Tengah Utara menunjukkan riwayat infeksi menjadi faktor risiko yang memiliki prediksi terjadinya stunting yakni sekitar 58 persen. Analisis multivariat menunjukkan bahwa riwayat infeksi ISPA dan diare berpeluang hampir 12 kali lebih besar mengalami stunting jika dibandingkan dengan anak yang tidak mengalami penyakit ISPA dan diare saat balita (Rosselo et al., 2019).

\section{Faktor risiko status gizi ibu ketika hamil}

Berdasarkan analisis statistik bivariat dengan metode Chi-Square menunjukkan hubungan antara faktor risiko status gizi ibu ketika hamil dengan stunting. Hal ini dibuktikan dengan nilai $p$ untuk faktor risiko status gizi ibu saat hamil adalah sebesar $0,004<0,05$. Nilai OR faktor risiko status gizi ibu saat hamil sebesar 7,2 yang dapat diartikan bahwa faktor status gizi kurang pada ibu saat hamil berisiko 7 kali terhadap kejadian stunting.
Pada analisis multivariat menunjukkan faktor risiko status gizi ibu saat hamil memiliki nilai $O R$ adalah sebesar 0,041 dengan nilai $p$ faktor risiko status gizi ibu saat hamil sebesar $0,001<\alpha$ 0,05 pada level kepercayaan $95 \%$ CI (0,006-0,294). Hal ini menunjukkan bahwa faktor risiko status gizi ibu ketika hamil memengaruhi kejadian stunting. Nilai OR sebesar 0,041, nilainya di bawah 1 , memberikan arti bahwa status gizi yang baik pada ibu saat hamil mencegah terjadinya stunting.

Kondisi sebelum dan selama kehamilannya pada wanita, kecukupan gizinya dapat memengaruhi status gizi ibu dan bayinya. Oleh karena gizi janin kebutuhannya bersumber dari ibu, maka pertumbuhan dan perkembangan janin dipengaruhi oleh asupan gizi makanan dari ibunya. Ketika ibu menderita kekurangan asupan gizi, maka akan berdampak pada risiko seperti BBLR, kelainan kongenital, retardasi mental, abortus, bayi lahir mati, perdarahan, dan sebagainya. Pada saat trimester akhir, ibu yang mengalami malnutris gizi, maka berisiko akan melahirkan anak yang memiliki berat badan lahir di bawah 2.500 gram (Astutik et al., 2018).

Ada berbagai macam ukuran yang menjadi parameter mengukur tubuh manusia, yakni: tinggi/ Panjang badan, berat badan, umur, lingkar lengan atas (LILA), lipatan kulit, dan lingkar kepala. Pemakaian Indeks Massa Tubuh (IMT) hanya untuk orang dewasa (di atas 18 tahun) dan tidak digunakan pada anak, remaja, dan bumil. Penilaian status gizi ibu Ketika hamil digunakan pengukuran LILA, untuk mengetahui kondisi seorang ibu menderita Kurang Energi Kronis (KEK) atau status gizi normal.

KEK keadaan di mana seseorang mengalami malnutrisi (kurang gizi) kalori dan protein, berlangsung kronis. Hal ini dapat ditandai dengan berat badan kurang dari $40 \mathrm{~kg}$ atau nampak tubuh kurus, LILA kurang dari $23,5 \mathrm{~cm}$. Intake kecukupan 
energi dan protein yang tidak atau kurang memenuhi pada ibu hamil akan berakibat menyebabkan ibu menderita kurang energi kalori. Wanita hamil dikatakan mengalami KEK, jika memiliki LILA di bawah 23,5 $\mathrm{cm}$. Ibu hamil menderita KEK, berisiko melahirkan anak dengan berat badan yang rendah ketika dilahirkan, dan apabila penanganan tidak segera dilakukan dengan baik, maka besar peluang berisiko mengalami stunting (Kemenkes RI, 2016; Astutik et al., 2018).

Pengamatan kasus stunting di Asia dan negara-negara berkembang oleh Apriluana dan Fikawati (2018), menunjukkan bahwa faktor status gizi ibu selama hamil akan berdampak pada berat bayi yang dilahirkan. Bayi yang memiliki berat badan lahir di bawah 2.500 gr, berpeluang lebih besar mengalami stunting, yakni sebesar 3,82 kali. Hal ini berarti bahwa balita dengan berat badan lahir kurang dari 2.500 gr berpelung mengalami stunting hampir 4 kali dibandingkan dengan balita yang saat lahir mempunyai berat lahir lebih 2500 gr.

\section{KESIMPULAN}

Usia saat hamil, status pendidikan ibu, riwayat diare balita, dan status gizi ibu ketika hamil memengaruhi kejadian stunting anak balita di Puskesmas Sangurara. Usia ibu ideal untuk hamil dan melahirkan merupakan intervensi yang memiliki kontribusi besar dalam menurunkan stunting. Wanita yang memiliki pendidikan tinggi berpeluang lebih dapat berinteraksi efektif dengan petugas kesehatan, lebih memanfaatkan fasilitas layanan kesehatan, dan lebih mudah mematuhi/ mengikuti informasi yang diberikan. Penyakit infeksi diare yang terjadi pada balita dapat menghalangi mencapai potensi pertumbuhan, sehingga berpotensi mengalami stunting. Asupan gizi ibu hamil memengaruhi perkembangan dan pertumbuhan janin selama berada di dalam rahim. Jika ibu ketika hamil menderita kurang gizi, maka ketika bayi lahir berpeluang menyebabkan berbagai risiko seperti BBLR dan anak kemungkinan akan mengalami stunting.

\section{UCAPAN TERIMAKASIH}

Ucapan terimakasih kepada UPTD Puskesmas Sangurara Kota Palu atas izin yanf diberikan kepada penulis untuk mengumpulan data penelitian di wilayah kerjanya. Ungkapan terima kasih pula disampaikan kepada ibu-ibu yang bersedia menjadi responden atas kesediaan telah meluangkan waktu dalam partisipasinya pada penelitian ini.

\section{DAFTAR PUSTAKA}

Alfadhila Khairil Sinatrya, \& Lailatul Muniroh. (2019). Hubungan Faktor Water, Sanitation, and Hygiene (WASH) dengan Stunting di Wilayah Kerja Puskesmas Kotakulon, Kabupaten Bondowoso. Amerta Nutrition, 3(3), 164-170. doi: $\quad 10.2473 /$ amnt.v3i3.2019.164170.

Apriluana, G., \& Fikawati, S. (2018). Analisis Faktor-Faktor Risiko terhadap Kejadian Stunting pada Balita (0-59 Bulan) di Negara Berkembang dan Asia Tenggara. Media Litbangkes, 28(4), 247-256.

Astutik, Rahfiludin, M. Z., \& Aruben, R. (2018). FAKTOR RISIKO KEJADIAN STUNTING PADA ANAK BALITA USIA 24-59 BULAN (Studi Kasus di Wilayah Kerja Puskesmas Gabus II Kabupaten Pati Tahun 2017). JURNAL KESEHATAN MASYARAKAT, 6, 409-418.

Balitbangkes. (2019). Laporan Nasional RISKESDAS 2018. In Badan Penelitian dan Pengembangan Kesehatan. Jakarta. Retrieved from http://labdata.litbang.kemkes.go.id/i mages/download/laporan/RKD/2018 
/Laporan_Nasional_RKD2018_FIN AL.pdf.

Desyanti, C., \& Nindya, T. S. (2017). Hubungan Riwayat Penyakit Diare dan Praktik Higiene dengan Kejadian Stunting pada Balita Usia 24-59 Bulan di Wilayah Kerja Puskesmas Simolawang, Surabaya. Amerta Nutrition, 1(3), 243. doi: 10.20473/amnt.v1i3.6251.

Hasan, A., \& Kadarusman, H. (2019). Akses ke Sarana Sanitasi Dasar sebagai Faktor Risiko Kejadian Stunting pada Balita Usia 6-59 Bulan. Jurnal Kesehatan, Volume 10, Nomor 3, November 2019 ISSN 2086-7751 (Print), ISSN 2548-5695 (Online) Http://Ejurnal.PoltekkesTjk.Ac.Id/Index.Php/JK, 10(3), 413. doi: 10.26630/jk.v10i3.1451.

Imelda, Rahman, N., \& Nur, R. (2018). Faktor risiko kejadian stunting pada anak umur 2-5 tahun di Puskesmas Biromaru. Ghidza: Jurnal Gizi Dan Kesehatan, Volume 2 No.1 (2018), 2(1), 39-43.

Kemenkes. (2020). Profil Kesehatan Indonesia Tahun 2019. In Indonesia. Kementerian Kesehatan. Jakarta. doi: 10.5005/jp/books/11257_5.

Kemenkes. (2021). Laporan Kinerja Kementrian Kesehatan Tahun 2020. In Kemenkes.

Kemenkes RI. (2016). Situasi Balita Pendek Di Indonesia. Kementerian Kesehatan Republik Indonesia, 110. Retrieved from https://pusdatin.kemkes.go.id/resour ces/download/pusdatin/infodatin/situ asi-balita-pendek-2016.pdf.

Kemenkes RI. (2018). Buletin Stunting. Situasi Balita Pendek (Stunting) di Indonesia. Kementerian Kesehatan RI, 1, 1163-1178.

Kementerian PPN/Bappenas. (2019). Kajian Sektor Kesehatan Pembangunan Gizi di Indonesia. In Kementerian PPN/Bappenas. Jakarta.
Kementerian PPN. (2020). Pedoman Teknis Penyusunan Rencana Aksi Edisi II Tujuan Pembangunan Berkelanjutan/ Sustainable Development Goals (TPB/SDGs). Kementerian PPN.

Larasati, D. A., Nindya, T. S., \& Arief, Y. S. (2018). Hubungan antara Kehamilan Remaja dan Riwayat Pemberian ASI Dengan Kejadian Stunting pada Balita di Wilayah Kerja Puskesmas Pujon Kabupaten Malang. Amerta Nutrition, 2(4), 392-401. doi: 10.20473/amnt.v2i4.2018.392-401.

Litbangkes. (2020). Rencana Aksi Program 2020-2024. Jakarta.

Profil Provinsi Sulawesi Tengah. (2020). Profil Kesehatan Provinsi Sulawesi Tengah Tahun 2019. In Dinas Kesehatan Sulawesi Tengah.

Rosselo, J., Kandarina, I., \& Kumorowulan, S. (2019). Faktor Risiko Stunting di Daerah Endemik Gaki Kabupaten Timor Tengah Utara. MGMI, 10(2), 125-136.

Setiawan, E., \& Machmud, R. (2018). Faktor-Faktor yang Berhubungan dengan Kejadian Stunting pada Anak Usia 24-59 Bulan di Wilayah Kerja Puskesmas Andalas Kecamatan Padang Timur Kota Padang Tahun 2018. Http://Jurnal.Fk.Unand.Ac.Id 277 Sebagian, 7(2), 275-284.

Sudikno, Irawan, I. raswanti, Setyawati, B., Wiryawan, Y., Puspitasari, dyah santi, Widodo, Y., Ahmadi, F., \& Amaliah, N. (2019). Laporan Akhir Penelitian Studi Status Gizi Balita Di Indonesia Tahun 2019. 190. Retrieved from https://cegahstunting.id/unduhan/pub likasi-data/.

Sutriyawan, A., \& Nadhira, C. C. (2020). Kejadian Stunting pada Balita di UPT Puskesmas Citarip Kota Bandung. Jurnal Kesmas (Kesehatan Masyarakat) Khatulistiwa, 7(2), 7988. doi: 10.29406/jkmk.v7i2.2072. 
Sutriyawan1?, A., \& Chantika Cindiana Nadhira2. (2020). KEJADIAN STUNTING PADA BALITA DI UPT PUSKESMAS CITARIP KOTA BANDUNG. JKMK JURNAL KESEHATAN MASYARAKAT KHATULISTIWA Http://Openjurnal.Unmuhpnk.Ac.Id/I ndex.Php? Journal=jkmk\&page $=$ ind ex.

Tatu, S. S., Mau, D. T., \& Rua, Y. M. (2021). Faktor-Faktor Resiko Yang Berhubungan Dengan Kejadian Stunting Pada Balita Di Desa Kabuna Kecamatan Kakuluk Mesak Kabupaten Belu. Jurnal Sahabat Keperawatan, 3(01), 1-17. doi: 10.32938/jsk.v3i01.911.

TNP2K. (2017). 100 Kabupaten/Kota Prioritas untuk Intervensi Anak Kerdil (Stunting). Jakarta.

Trihono, Atmarita, Tjandrarini, D. H., Irawati, A., Utami, N. H., Tejayanti, T., \& Iin Nurlinawati. (2015). Pendek (Stunting) di Indonesia, Masalah dan Solusinya (Vol. 148).

Venuz, P., Lema, V., Setiono, K. W., \& Manubulu, R. M. (2019). Analisis Faktor Risiko Kejadian Stunting Pada Balita. Cendana Medical Journal, 17(3), 249-259.

Wahyuni, D., \& Fithriyana, R. (2020). Pengaruh Sosial Ekonomi Dengan Kejadian Stunting Pada Balita Di Desa Kualu Tambang Kampar. PREPOTIF: Jurnal Kesehatan Masyarakat, 4(1), 20-26. doi: 10.31004/prepotif.v4i1.539.

Wahyuni, N., Ihsan, H., \& Mayangsari, R. (2019). Faktor Risiko Kejadian Stunting pada - Balita Usia 24 - 36 Bulan di Wilayah Kerja Puskesmas Kolono. Jurnal Kesehatan Masyarakat, 9(2), 212-218.

Windiarto, T., Yusuf, A. H., Santoso, A. D., Nugroho, S., Latifah, S., Solih, R., Hermawati, F., Purbasari, L. A., \& Rahmawatiningsih, A. (2018).
Profil Kesehatan Anak Indonesia Tahun 2018. In Kementerian Pemberdayaan Perempuan dan Perlindungan Anak (KPPPA) dan Badan Pusat Statistik (BPS). Jakarta. 